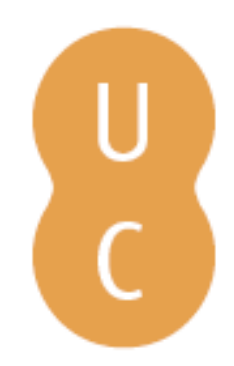

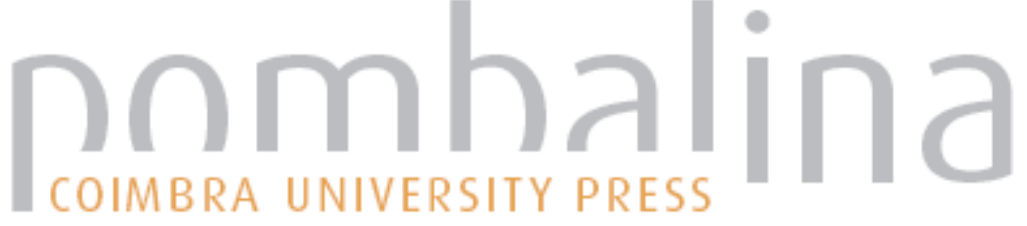

\section{Nas raízes da tolerância}

Autor(es): $\quad$ Pascoal, Augusto Ascenso

Publicado por: Imprensa da Universidade de Coimbra

URL

persistente: URI:http://hdl.handle.net/10316.2/38962

DOI: $\quad$ DOI:http://dx.doi.org/10.14195/978-989-26-0395-7_16

Accessed : $\quad$ 26-Apr-2023 13:55:18

A navegação consulta e descarregamento dos títulos inseridos nas Bibliotecas Digitais UC Digitalis, UC Pombalina e UC Impactum, pressupõem a aceitação plena e sem reservas dos Termos e Condições de Uso destas Bibliotecas Digitais, disponíveis em https://digitalis.uc.pt/pt-pt/termos.

Conforme exposto nos referidos Termos e Condições de Uso, o descarregamento de títulos de acesso restrito requer uma licença válida de autorização devendo o utilizador aceder ao(s) documento(s) a partir de um endereço de IP da instituição detentora da supramencionada licença.

Ao utilizador é apenas permitido o descarregamento para uso pessoal, pelo que o emprego do(s) título(s) descarregado(s) para outro fim, designadamente comercial, carece de autorização do respetivo autor ou editor da obra.

Na medida em que todas as obras da UC Digitalis se encontram protegidas pelo Código do Direito de Autor e Direitos Conexos e demais legislação aplicável, toda a cópia, parcial ou total, deste documento, nos casos em que é legalmente admitida, deverá conter ou fazer-se acompanhar por este aviso.

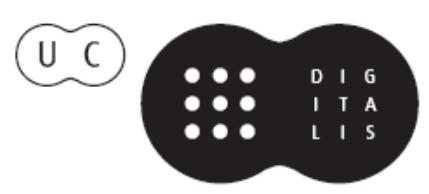


Nair de Nazaré Castro Soares

Santiago López Moreda

Coordenação

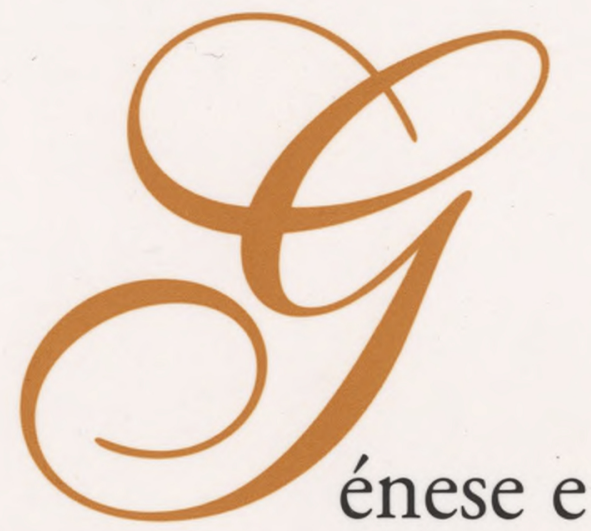

Consolidação da Ideia de Europa

Vol. IV

Idade Média e Renascimento

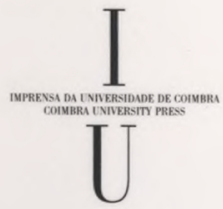

- COIMBra 2009 


\title{
NAS RAÍZES DA TOLERÂNCIA ${ }^{1}$
}

\author{
Augusto Ascenso Pascoal \\ (Universidade Católica Portuguesa)
}

INTRODUÇÃO

Nos finais do século IX, o Papa João VIII, perante a ameaça dos sarracenos, que infestavam as costas do Mediterrâneo, convidava os príncipes cristãos a uma aliança que fosse mais do que ocasional: que dessem coesão política e defensiva à unidade cultural que constituíam já e à qual se dava pela primeira vez o nome de Europa.

Convém notar que nesta altura grande parte do continente, sobretudo a Leste, ainda não tinha abraçado o cristianismo: é precisamente João VIII que dá um impulso decisivo à evangelização dos eslavos, apoiando o trabalho dos irmãos Cirilo e Metódio.

Está, no entanto, claro que a matriz dessa unidade, constituída por povos de raças e culturas diferentes e que o Papa designa por Europa, tem a ver com uma visão peculiar do homem e dos valores que integram a sua existência histórica, que se não era ainda comum, estava à beira de o ser.

Não vamos entrar agora na polémica sobre as raízes cristãs da Europa, ainda que seja nossa convicção de que, mais tarde ou mais cedo, ela terá de ser retomada, se não quisermos perder definitivamente algumas das pistas fundamentais para a definição do que será de facto um verdadeiro espírito europeu.

Porque não é de religião, mas de cultura, que se trata.

Uma dessas pistas será a capacidade de síntese e integração, no campo dos valores, que lhe vem do fundo cristão do seu pensamento: precisamente o

${ }^{1} \mathrm{Na}$ sua substância, o conteúdo deste trabalho, em certos casos, a própria forma, encontram-se em Aquiles Estaço, Humanista Teólogo, dissertação de doutoramento em Literatura Latina, defendida na Faculdade de Letras da Universidade de Coimbra, a 19 de Dezembro de 2002. 
ecumenismo que se quis salvar omitindo, no Prólogo do Tratado Constitucional da União, a referência às raizes cristãs da Europa.

Apesar de todos os acidentes de percurso, avanços e recuos, dos desvios, alguns dos quais pareciam anunciar a perda do rumo inicial, o que se passa no velho continente, de finais do século IX a meados do século XVII - com o tratado de Vestefália a consumar a obra que quis evitar - é a gestação de um espaço cultural que resiste aos nacionalismos mais exacerbados e que tem como fio condutor, mesmo nos momentos de maior esquecimento da transcendência, três frases do escrito mais antigo do Novo Testamento: "Não apagueis o Espírito. Não desprezeis as profecias. Examinai tudo, guardai o que é bom" (1Tessalonicenses, 5, 18-21).

É este examinar tudo e conservar o que é bom que permite às culturas antigas - não apenas a greco-romana, mas também as que lhe servem de substrato - entrar em fusão com uma visão radicalmente nova do destino humano e dar corpo a um espaço cultural que não foi possível com nenhuma outra antropologia.

Momentos altos desta gestação, que se tornam evidentes até pelas crises que provocam, são as aparentes redescobertas da Antiguidade a que se deu impropriamente o nome de renascimentos: afinal, o que se passa é a exaltação de alguns aspectos dessa Antiguidade que, quando reencontram o seu lugar no espaço já criado, por uma osmose que chamaríamos vital, provocam o surgir de formas de arte e estilos de vida que, sem deixarem de ser novos, guardam, no entanto, as características essenciais da sua matriz.

Para nos não alongarmos demasiado e ficarmos dentro da língua e do modo de ser português, poderíamos perguntar-nos se não seria oportuno analisar nesta perspectiva, por exemplo, aquilo que, sem grande rigor de critérios, se chamou de "estilo manuelino".

E que diríamos d'Os Lusíadas, que Jorge de Sena muito justamente aponta como um repositório de dezasseis séculos de cultura?

1. Vem tudo isto a propósito de Aquiles Estaço, contemporâneo de Camões, nascido, como ele, em plena florescência do manuelino, que também se chama renascença portuguesa.

A crítica histórica terá de percorrer ainda um largo caminho para que a historiografia se liberte de muitos lugares comuns e ideias preconcebidas, que, sobretudo no que diz respeito ao que se escreve em Portugal, continuam a condicionar, não apenas a linguagem, mas o próprio trabalho de pesquisa.

Teriam de se multiplicar os estudiosos que partissem para a investigação conduzidos pelo desejo de encontrar $a$ verdade, mais do que pela ânsia de confirmar uma verdade. 
Por exemplo, em Portugal, apesar das excepções que já aparecem no nosso panorama científico, a historiografia continua dependente da imagem da Idade Média criada pelos humanistas do século XIV, e quase se não conhece outro conceito de Reforma senão o que foi divulgado pelos historiadores protestantes, que criaram também o conceito de Contra-Reforma, ainda que já na segunda metade do século XVIII e com um significado diferente do que se the dá hoje ${ }^{2}$.

Toda a gente sabe que Lutero e os seus primeiros discípulos, pegando na palavra Reformatio (al. die Reformation), retirada dos esquemas conciliares do século XV - De reformatione Ecclesiae in capite et in membris - quiseram apenas dizer que procuravam levar por diante a reforma da Igreja que todos pareciam desejar, mas que ninguém conseguia tornar efectiva.

Ainda que contra a sua vontade inicial, o que o monge agostinho fez foi uma autêntica revolução, não propriamente uma reforma da Igreja.

De facto, com Lutero, põem-se em questão aspectos essenciais do cristianismo e altera-se por completo o mapa religioso da Europa.

No mais aceso da polémica, com interesses políticos a meterem-se por todos os lados, extremam-se os campos, e a tão desejada reforma da Igreja só não se adia mais uma vez, porque reformar-se pertence à sua própria dinâmica.

Movimentos de renovação cristã, na perspectiva do crente, surgem em todas as épocas, como fruto da acção do Espírito Santo no coração dos fiéis.

São desse tipo movimentos, por exemplo, como as fundações levadas a cabo por grandes carismáticos, como Bento de Núrcia (e todos os reformadores da sua linha), Bernardo de Claraval, Francisco de Assis, Domingos de Gusmão, etc., para falarmos apenas dos principais do ocidente europeu, entre os séculos V e XIII.

Mas, no contexto das presentes reflexões, estão a referir-se os movimentos de renovação cristã surgidos num ambiente peculiar da Igreja ocidental, nos finais da Idade Média, quando o continente se transformava em todos os sentidos, e as consciências mais esclarecidas se davam conta da necessidade de um regresso às exigências do Evangelho; o que reclamava também uma alteração das estruturas eclesiásticas, demasiado dependentes da função política, então desempenhada por grande parte dos membros da Hierarquia, sobretudo nas regiões do norte da Europa.

${ }^{2}$ Cf. Hubert JEDIN, Katholische Reformation oder Gegenreformation? Ein Versuch zur Klärung der Begriffe nebst einer Jubiläumsbetrachtung über das Trienter Konzil. Verlag Iosef Stocker - Luzern 1946. Utiliza-se aqui a quinta edição italiana. Brescia, Editrice Morcelliana, 1995, pp 13 e sgs. 
Ao apoderarem-se do termo Reformatio, que trazia já um significado teológico-canónico muito específico, os discípulos de Lutero, querendo afirmar simultaneamente a novidade do seu movimento e o radicalismo da resposta que, segundo eles, dava aos anseios da Cristandade, talvez sem pensarem nisso, provocaram o corte com os movimentos de renovação que vinham surgindo na Igreja, desde finais do século XIV.

Isso vem criar um problema de dupla dimensão: do ponto de vista sincrónico, os que mais haviam lutado, não apenas por uma reforma das estruturas eclesiásticas, mas por uma autêntica renovação da vida cristã, cujas exigências iam muito para além daquela reforma, viram-se subitamente entre fogos cruzados, com os meios intelectuais divididos em duas posições cada vez mais radicalizadas e, consequentemente, cada vez menos conciliáveis.

O pior é que a agitação provocada pelo envolvimento político de Lutero faz com que se esqueçam os reformadores moderados - que os havia de ambos os lados da barricada -, e a história deste período começa a ser marcada de uma forma verdadeiramente maniqueia, com os historiadores a ver o bem totalmente separado do mal e colocando-os frente a frente, segundo as próprias simpatias.

De facto, o maniqueísmo político está subjacente a todas as ideologias que servem de fundamento à intolerância e à ditadura, um abuso do poder possível em qualquer campo da vida humana; e que se insinua também na análise dos fenómenos do passado, sempre que nos esquecemos de que ninguém, do lado de cá da história, tem o monopólio da verdade.

É por isso que termos como Reforma e Contra-Reforma, sobretudo quando com aquela se identificam as auto - designadas igrejas evangélicas, e com esta a acção da Igreja Católica, em ordem à sua renovação interna, estão na base de muitos erros de simplificação que, além do mais, levam a graves injustiças contra pessoas e instituições.

Temos o exemplo de Aquiles Estaço, que poderíamos comparar com Damião de Góis, já que são quase contemporâneos.

Sabemos que, a nível do pensamento europeu, sobretudo como filólogo, Estaço, cuja autoridade é invocada ainda no século XVII, foi mais conhecido e apreciado do que Góis. E, quanto a abertura de espírito, não parece que os contactos internacionais deste, que não foram mais vastos nem mais variados que os daquele, documentem uma modernidade superior à que se pode divisar em muitos aspectos da vida e dos escritos do autor do De Reditibus ecclesiasticis et De Pensionibus ${ }^{3}$.

${ }^{3}$ São dois tratados que Aquiles Estaço publica formando um todo, pela primeira vez, em 1575, com o título Achillis Statii Lusitani De Reditib. Ecclesiasticis Qui Beneficiis et 
2. Na perspectiva deste trabalho, e quando falamos de grandes sínteses culturais que definem de certo modo o que designámos por "espírito europeu", importa referir, antes de mais, o que terá sido o grande projecto literário e teológico de Aquiles Estaço, que chega a Roma provavelmente nos últimos anos da década de cinquenta, do século XVI, e aí morre em 1581. Isto é, passa na Cidade Eterna acima de vinte anos, que correspondem ao terço mais produtivo da sua vida.

Para uma referência, necessariamente muito superficial, ao contributo de Aquiles Estaço para a formação de um espírito europeu, podemos tomar, entre outras, duas pistas, ou, se quisermos, dois pontos de referência, ou seja: a criação poética, como projecto e como realização, por um lado, e os comentários bíblicos, por outro.

A um de Março de 1566, Aquiles Estaço dedicava a Jerónimo Rusticucci, secretário particular do Papa Pio V, uma edição comentada dos poemas eróticos de Catulo, com palavras a partir das quais ficamos a saber duas coisas muito importantes:

A primeira é que ele, desde a sua juventude, concebera o projecto de traduzir em verso latino os textos poéticos da Bíblia; projecto que, em 1566, quinze anos antes da sua morte, continuava vivo, ainda que adiado, pelos muitos afazeres que pesavam sobre os ombros do humanista.

A segunda coisa que ficamos a saber é que ele, pelas exigências desse mesmo projecto e enquanto não podia concretizá-lo de outro modo, ia aperfeiçoando os dotes que queria pôr ao seu serviço, estudando a poesia clássica latina.

Desse estudo intercalar e dos exercícios que implicava, temos frutos preciosos, para além da referida edição dos poemas eróticos de Catulo.

Também como reflexão intercalar, talvez possamos tirar algumas ilações do facto de Aquiles Estaço fazer esta edição em pleno pontificado de Pio V, que fora o responsável máximo da Inquisição Romana, no tempo de Paulo IV, e que os historiadores apresentam como uma das figuras mais típicas daquilo que se convencionou chamar Contra-Reforma.

Mais, Aquiles Estaço dedica esta edição dos poemas de Catulo, profusamente anotada, com explicações de todo o tipo, incluindo os termos mais escabrosos, relativos à vida intima do protagonista ou dos protagonistas desses

Pensionib. Continentur. Commentarioli. II.(...) ROMAE. (...) Anno Iubilaei. M.D.LXXV. Em 1581, o ano da sua morte, faz uma nova edição, integrando no texto as notas marginais que escrevera na anterior. Os dois exemplares que foram propriedade do autor encontram-se na Biblioteca Vallicelliana, reunidos numa miscelânea, com a cota, S. Borr. I. V. 104 (1-4). 
poemas, a Jerónimo Rusticucci, secretário particular do Papa; um homem da Cúria, que o conhecia muito bem e ao qual o humanista português devia especiais favores.

É bom notar que Estaço, prevendo o aparecimento de objecções ao cuidado que pôs na edição de Catulo, se defende com um raciocínio muito parecido com o que usa Bartolomeu Ferreira, no seu parecer para a edição d'Os Lusiadas: e a poesia deve ser apreciada como arte e não como edificação.

\section{VESTIGIO DE UM PROJECTO GRANDIOSO?}

Não sabemos que tipo de poesia terá Aquiles Estaço cultivado no período que antecede a sua partida para Paris e Lovaina, onde se dedica à Teologia $\mathrm{e}$ aperfeiçoa os conhecimentos alcançados no convívio com os melhores humanistas portugueses do tempo, entre os quais se contam André de Resende e os intelectuais do seu círculo.

Do que foi publicado a partir de 1547, ano da edição de Syluulae duae, podemos concluir com segurança que tentou a poesia em todas as áreas da inspiração poética.

Merece especial referência a sua poesia religiosa.

Ainda que, para a esperança de vida do tempo, Aquiles Estaço não tenha morrido especialmente jovem, podemos considerar o que nos deixou, neste domínio, o esboço de um projecto que podemos considerar grandioso.

De facto, escrever em verso latino tudo o que na Sagrada Escritura é considerado texto poético - e não nos esqueçamos de que Aquiles Estaço tinha um conhecimento suficiente do hebraico, para se dar conta da vastidão da tarefa que se impunha - seria uma empresa realmente extraordinária.

A pensar nela, o nosso humanista realizou um trabalho insano, compulsando manuscritos antigos, corrigindo textos, tirando notas...

Os resultados desse trabalho tiveram aplicações múltiplas, devido ao carácter multifacetado da actividade desenvolvida em Roma por Aquiles Estaço.

Mas o projecto da sua juventude ficaria por realizar; não sabemos se por demasiado ambicioso, se por falta de tempo. Provavelmente por ambas as razões, que acabam fundindo-se na vida que Aquiles Estaço é obrigado a viver em Roma: a vastidão do projecto exigiria uma disponibilidade total que, na segunda metade do século XVI, já nenhum humanista podia ter, sobretudo se empenhado, como era o caso do nosso compatriota, num verdadeiro trabalho de renovação interna da Igreja. 
Podemos assim afirmar que lhe faltou o tempo - na linha da sincronia (tempo disponível) e na linha da diacronia (tempo vivido) - também pelo carácter, digamos, excessivo do seu projecto.

No ano de 1549, saía em Paris, dos prelos de Thomas Richard, o seu segundo livro impresso.

Na dedicatória desta obra ao Infante D. Luís, filho de D. Manuel, portanto, irmão do rei D. João III, há, entre outras coisas de interesse, o passo seguinte:

Ac sunt hi quidem quos accipis princeps clarissime ocii mei fructus: non enim haec scribo nisi uacuus, et a Theologiae studiis aliquantulum feriatus. Idque facio, quo musas, quas olim puer magno studio colui, etiam nunc grandior, et quidem Theologus, retineam.

Ou seja, em tradução livre:

"O que estás a receber, príncipe ilustre, são apenas os frutos do meu ócio; pois não escrevo tais coisas senão quando estou livre e um pouco aliviado dos meus trabalhos de Teologia. E faço-o, para que eu, que tão intensamente cultivei as musas, enquanto era jovem, também as conserve comigo agora, que sou mais velho e, ainda por cima, Teólogo."

As palavras do nosso humanista inspiram as seguintes observações:

1. Os trabalhos que integram este opúsculo são o fruto da ocupação dos tempos que a sua actividade normal the deixava livres - ocii mei fructus.

Tendo presente o significado clássico do termo otium, e o que escreve no período seguinte, é legítimo pensar que, na mente do seu autor, o conteúdo deste opúsculo correspondia a algo que tinha grande importância, inclusive para o que estava no centro das suas preocupações, ou seja, a teologia: Idque facio, quo musas... etiam nunc grandior, et quidem theologus, retineam.

2. Aquiles Estaço era um estudante de Teologia aplicado; o que pode explicar, tanto a segurança com que aborda muitos dos temas controvertidos, na sua época, como a riqueza de conteúdo das notas que escreveu nas margens de alguns dos livros da sua biblioteca.

3. Cultivou a poesia quando era jovem: quo musas quas olim puer magno studio colui... retineam.

4. Considera-se a si próprio teólogo. Este facto permite-nos, pelo menos, suspeitar de que a Teologia foi uma preocupação de sempre na mente do nosso humanista. E a partir dele podemos também duvidar da justeza da afirmação que atribui à sua presença em Roma o interesse pela Teologia. 
É, portanto, claro que Aquiles Estaço cultivou a poesia enquanto era jovem e quer continuar a cultivá-la: porque gosta de poesia, mas também porque, como fica dito, ela entra nos seus projectos de estudante de Teologia: quo musas retineam, nunc grandior et quidem theologus.

Quais sejam esses projectos, não o diz aqui, senão indirectamente, na medida em que afirma querer continuar a cultivar a poesia enquanto teólogo nunc grandior et quidem theologus.

Mas di-lo-á mais tarde, como vimos acima, precisamente quando, decorridos dezassete anos, dedicar a outro amigo - agora da Cúria Romana - os resultados de outros ócios, que eram, afinal, se virmos bem as coisas e como o termo insinua, trabalhos relacionados com o grande projecto da sua vida, aqui referido de forma indirecta.

Entretanto, não será extrapolar demasiado se, tendo em vista aquele et quidem theologus, concluirmos que Aquiles Estaço pressentia, pelo menos, a existência de uma especial relação entre a poesia e a Teologia: o que certamente, além de se dever à intuição dos humanistas em geral, para quem o estudo da Retórica estava longe de corresponder a um intuito meramente estético, se descobria no contacto com as fontes da Teologia, sobretudo a Bíblia e uma parte dos Padres.

De facto, não será por acaso que uma grande parte dos escritos bíblicos são, literariamente falando, obras poéticas e, mesmo os que pertencem a outros géneros, contêm inúmeros textos poéticos.

Bem vistas as coisas, se guardamos um conceito suficientemente amplo de poesia (poesis/poietikós), temos de admitir que, como, aliás, acontecia já com os filósofos da Antiguidade, o casamento, digamos assim, da Teologia com a poesia se torna patente nos textos bíblicos, sobretudo do Antigo Testamento, na proporção directa da sublimidade da mensagem que transmitem.

É o que acontece com os escritos dos profetas e os Livros Sapienciais, nos quais se inclui o Saltério.

No Novo Testamento, se deixamos de lado os hinos que São Paulo incluiu nas suas cartas e alguns discursos de Jesus, nomeadamente as parábolas, pode dizer-se que o texto mais poético é o quarto evangelho, cuja sublimidade fez com que a primitiva comunidade cristã desse a João o título de «Teólogo».

Os Padres, principalmente de expressão grega, e são quase todos, nos dois primeiros séculos da era cristã, não precisam sequer de inventar a técnica, que lhes vinha dos grandes filósofos da Antiguidade e se mantinha presente nas escolas, sobretudo devido à permanência do prestígio de Platão e dos seus grandes mitos. 
Será por isso que, pelo menos até ao século XII, no Ocidente, os temas da fé mais abordados pela poesia são os que se relacionam com os grandes mitos cosmológicos, como é o caso da criação e do significado teológico do mundo: aqui há uma influência profunda do Timeu, talvez a obra de Platão mais lida no Ocidente, ao longo de toda a Idade Média.

A partir do século XII, por influência de São Bernardo, primeiro, e de São Francisco, depois, a poesia invade todos os temas da vida cristã, mas com um pendor mais místico, que se reflectirá na criação poética de Aquiles Estaço, embora não possamos considerar a sua poesia como poesia mística.

\section{AQUILES ESTAÇO, POETA CRENTE}

Em face disto, já não será necessário insistir que os escritos espirituais de Aquiles Estaço, nomeadamente os que se relacionam com novas versões dos textos sagrados, não pertencem a um projecto da velhice, de um humanista que, como diria o Camões das redondilhas "Sôbolos rios que vão», cantasse a sua palinódia.

É claro que Aquiles Estaço não tem a envergadura poética de Camões, nem a profundidade filosófica e a força mística de Pascal.

Mas as razões por que aqui se mencionam essas duas figuras cimeiras da história cultural europeia são outras.

A primeira está no facto de tanto Camões como Pascal documentarem diferentes sortes do inacabado. Pois, enquanto, para o pensador francês, ele se transforma numa das fontes de engrandecimento da sua imagem, pelo que, no esboço da Apologie de la Réligion Chrétienne, fica da riqueza do seu pensamento, para o poeta lusíada, a dispersão dos seus poemas líricos constitui uma deficiência fatal, que ameaça fechar para sempre aos seus leitores a grandeza da alma que quis falar através dos seus poemas.

A segunda razão parte do facto de Camões ser perfeitamente contemporâneo de Aquiles Estaço, quer pelos anos em que viveu - quase lado a lado, se não no espaço, seguramente no tempo, um com o outro, embora talvez desconhecendo-se mutuamente - quer pelas ideias que, modeladas no que de melhor produziu o Renascimento português, guiaram a sua criatividade e perpassam os textos mais significativos de ambos.

E não seria de todo descabido estudá-los na perspectiva do moderno pensamento europeu, naquilo que tem de melhor e mais específico.

Claro que há entre eles uma diferença abissal, se reparamos no génio poético de cada um, partindo do que nos resta da obra respectiva. 
O autor de Os Lusiadas não sofre comparação com nenhum artista do seu tempo, nem talvez com nenhum daqueles que, no mundo ocidental, se seguiram ao seu mestre e modelo: ou seja, Virgílio Nasão.

Aquiles Estaço, enquanto criador artístico, é, sem dúvida, inferior a Camões: se fosse preciso, bastaria, para nos convencermos disso, comparar a paráfrase que ambos fazem do Salmo 136, ou 137, segundo a numeração da bíblia hebraica, que é a que, neste caso, segue o nosso humanista.

Claro que, independentemente da maior ou menor genialidade, no que se refere à inspiração poética, não podemos esquecer a diferença de posições, perante o texto sagrado. Este, como sabem os especialistas dos géneros literários da Bíblia, sem deixar de ser um texto humano, com todas as características do género a que pertence, reflecte uma fé à qual procura ser fiel, e, segundo a doutrina da inspiração sobrenatural, desenvolve-se dentro de fronteiras especiais, que não existem para a criação puramente humana.

Ora, é evidente que, enquanto Camões podia pegar no salmo como simples fonte de inspiração, Aquiles Estaço, quer pela sua formação teológica, quer pelo contexto em que insere a sua versão, sentir-se-ia necessariamente mais limitado pelas fronteiras provenientes do carácter sagrado do texto.

Por outro lado, mesmo sem entrarmos na já referida polémica SérgioSena, pode dizer-se que o texto do nosso épico pertence, com todo o direito, à poesia mística portuguesa do século XVI, enquanto o de Aquiles Estaço não pode senão incluir-se na poesia de tema religioso.

$\mathrm{Se}$, no campo da poesia religiosa, distinguirmos aquela que apenas se inspira na religião e a que se ocupa das verdades da fé, podemos então falar de poesia religiosa, no primeiro caso, e teológica, no segundo.

Estaço cultiva as duas.

\section{ECUMENISMO E FÉ NA MISERICÓRDIA DIVINA}

Por estranho que pareça, sobretudo se tivermos em conta uma certa imagem criada nos últimos séculos relativamente ao humanismo da Reforma, nem Lutero nem os seus discípulos imediatos favoreceram muito o discurso sobre a misericórdia divina.

De facto, ao querer realçar o carácter absolutamente gratuito da salvação, no que estava perfeitamente de acordo com a tradição teológica mais genuína, não soube evitar o escolho em que o próprio Santo Agostinho esteve à beira de soçobrar, quando polemizava com os pelagianos, demasiado confiantes nas capacidades da natureza humana. 
Pode dizer-se que todas as controvérsias do século XVI sobre a justificação e a graça, após o Concílio de Trento, principalmente dentro da Igreja Católica, onde nunca cessaram as tentativas de estabelecer pontes que permitiss em o diálogo com os teólogos da Reforma, se balanceiam entre estes dois extremos: o que leva muitas vezes ao esquecimento do essencial, definido na célebre sessão sexta daquele Concílio, mas que corresponde aos aspectos mais importantes de tudo quanto, depois de São Paulo, se ensinou sobre a radical novidade de Jesus Cristo, que nos veio revelar os extremos do amor do Pai .

Da sua poesia de Aquiles Estaço, tomamos apenas um exemplo:

$\mathrm{O}$ poema Cuius querellas gentis ante et flebile, inspirado na história do Povo Hebreu, que Deus, mediante maravilhas de vária ordem, liberta da escravatura do Egipto e depois conduz através do deserto, até à sua chegada à Terra Prometida, ou seja ao vale do Jordão:

Deus escuta as queixas do Seu Povo ( $E x$ 3, 7 sgs.), o mesmo que manifesta a sua alegria depois da libertação e da extraordinária travessia do Mar Vermelho (Ex 14.), as dificuldades da travessia do deserto e as obras maravilhosas - isto é, dignas de serem vistas e cantadas - com que Deus acode aos Seus eleitos (Ex 16-17.).

Destas, o poeta menciona expressamente:

A travessia do mar a pé enxuto (Ex 14, 15-30, vv 5-8).

Já no deserto, o alimento vindo do céu - o maná e as codornizes (Ex 16, vv 9-13).

Depois, ainda no deserto, a água que jorra da rocha, após as pancadas ordenadas por Deus e executadas, aliás, numa atitude de pouca fé, por Moisés (Ex 17, 1-7, vv 13-16),

Não se publica o texto latino para abreviar, ainda que formalmente seja um bom exemplo de poesia neo-latina.

Além disso, tem interesse notar a riqueza emotiva que Aquiles Estaço consegue incutir no seu poema pelo estilo pessoal que utiliza, pondo-se no lugar do povo escravizado, até aos versos finais, onde com uma linguagem que nos faz pensar em Virgílio $($ Aen. 1,$94 ; 12,155)$, felicita esse povo, por ser regido, defendido e guiado por um Deus que compara o cuidado com que protege o Seu povo à ternura da galinha protegendo os pintainhos sob as suas asas; uma imagem de profundas ressonâncias bíblicas, que não encontramos no Antigo Testamento, mas que nos leva até lá, a partir de Jerusalém, sobre a qual Lucas constrói essa outra imagem da misericórdia divina, que é Jesus chorando sobre o destino trágico da Sua Pátria (Cf Mt 23, 37; Lc 13, 34$-35 ; 19,41-44)$. 
Do poema do humanista português propõe-se a seguinte tradução:

Do povo cujas lamentações, antes, em minha poesia,

Cantava, em canto queixoso e triste,

Esqueço as penas e [canto] agora a admirável alegria,

Depois que deixou de ser escravo.

Ovante percorreu, para a pátria, ínvios caminhos;

E o fundo do mar a pé enxuto,

Enquanto do mar as águas param, aqui e ali,

Pisarei, conduzido por Deus.

Faltava àquele que deambula por caminhos ínvios

Alimento que debelasse a fome?

Caía do alto céu, como orvalho,

A esperança de banquete mais lauto.

Recusava aquele solo árido

$\mathrm{O}$ líquido com que se extinguisse a sede?

Eis que uma nascente brotava da rocha,

E rios corriam entre as pedras.

Oh, três e quatro vezes bem-aventurado o povo que Deus

Governa, protege e conduz!

$\mathrm{E}$ isso como a galinha, que de toda a parte

Congrega os seus pintainhos.

Ora, desta revelação, em termos de linguagem verbal, o discurso mais belo, até do ponto de vista literário, encontra-se em Lucas, capítulo XV, versículos 11-31.

É a chamada parábola do Filho Pródigo, que Jesus contou, como é fácil de ver, com o apoio de todo o contexto deste capítulo, não para falar do filho, mas para revelar os abismos de misericórdia do Pai .

Aquiles Estaço deixou muitas apostilas no Evangelho de Lucas; porém, quanto ao capítulo quinze, que contém as três parábolas da misericórdia divina, debruçou-se de modo especial sobre a parte referente à terceira, a única que apostilou.

No seu trabalho, manifesta-se a cada passo o filólogo, preocupado com a autenticidade do texto, que procura comentar com a ajuda dos Padres da Igreja e outros testemunhos da Tradição.

E esta é primeira nota de modernidade, importante, não por ser original, mas por denunciar uma linha de "contra-reforma" que não costuma referir-se, até porque não corresponde ao conteúdo semântico actual da palavra.

Mas nas notas a esta parábola encontramos também algumas reflexões pessoais sobre o pecado, a conversão e a misericórdia divina, que servem para documentar, mais uma vez, a posição de Estaço, entre os fogos cruzados dos controversistas do seu tempo. 
São notas de grande importância teológica às quais se pode dar uma ordenação sistemática, seguindo muito de perto a estrutura narrativa do texto de Lucas, 15, 11-32.

De forma muito sumária, essa estrutura pode desenhar-se assim:

O filho mais novo, uma vez recebida do pai a parte que lhe cabia na herança, parte para «uma região longínqua» (11-13).

Consequências do afastamento da casa paterna (14-16).

O filho tresmalhado recorda-se da casa do pai, mede o estado em que se encontra e decide regressar (17-19).

A festa do reencontro (20-24).

O pai justifica-se perante o filho mais velho (25-32).

Como é fácil de ver, a cada troço narrativo corresponde um momento importante daquilo que poderíamos designar por dinâmica do pecado e da conversão, vista, tanto do lado do pecador, que ofende, como do lado de Deus, que perdoa.

Como para o nosso intento interessa sobretudo o comentário de Estaço ao último troço narrativo, passamos a ele imediatamente.

O clímax atinge-se no versículo 20 , quando o pai, ao ver o filho ainda longe, se lhe lança ao pescoço, cobrindo-o de beijos:

Cum autem adhuc longe esset, uidit illum pater ipsius et misericordia motus est et accurrens cecidit supra collum eius et osculatus est illum.

A descoberta de Lucas como o evangelista da misericórdia divina, mais preocupado em captar os gestos e as palavras que revelam essa misericórdia do que em descrever o percurso da conversão por parte do pecador - ou não fosse ele discípulo de São Paulo - esta descoberta é relativamente recente, na exegese católica.

Isso explicará o facto de o nosso humanista não ter deixado qualquer nota a este versículo, que, segundo tudo leva a crer, foi objecto de um cuidado especial por parte do redactor do texto evangélico.

Aliás, ainda hoje, como o documenta o nome que se dá a esta parábola, o texto é lido mais na perspectiva dos actos do pecador do que pensando no amor misericordioso de Deus.

Aquiles Estaço escrevia na segunda metade do século XVI, após a polémica com os reformadores, que negavam ao pecador toda a possibilidade de cooperar com Deus na sua conversão.

Contra eles se dirigiam de modo especial os cânones do Concílio de Trento, que, sem negarem o facto de ser Deus a tomar a iniciativa, afirmavam igualmente a capacidade de o homem colaborar com Ele. 
Num ambiente de controvérsia, como era, a este respeito, o século XVI, qualquer tendência a acentuar um dos aspectos poria de sobreaviso os defensores dos outros, que não hesitavam em classificar de hereges os que não estavam claramente do seu lado.

Além disso, é normal que um humanista do século XVI, desejoso de contribuir para a formação prática dos crentes, no sentido de realizarem correctamente os actos correspondentes à doutrina fixada pelo Concílio, fale da conversão, mais na perspectiva do pecador do que na de Deus.

E este era o caso do nosso humanista.

Assim, põe em realce a sinceridade do filho e a corajosa humildade com que reconhece ter ofendido Deus e o pai: Pater, peccaui in caelum et coram te.

Estaço lê a expressão peccaui in caelum, enquadrando-a na situação concreta do guardador de porcos, conseguindo assim tirar dela um partido especial: Peccaui in caelum, quo nunquam oculos sustuli more porcorum quos paui.

Que se confessa indigno de ser considerado filho de tal pai, mas trata-o como tal, na esperança de alcançar o perdão.

$\mathrm{E}$ quanto ao cum autem adhuc longe esset, parecem interessar-lhe mais os aspectos canónicos da conversão e os seus efeitos imediatos do que a iniciativa de Deus e a generosidade do Seu perdão: assim, fala dos frutos da contrição, sem deixar de referir a necessidade da confissão auricular, si possit fieri.

É a doutrina confirmada pelo Concílio de Trento, ainda hoje presente na pastoral do sacramento da Reconciliação .

No entanto, além das referências indirectas, contidas nas alusões à conversão do pecador, Aquiles Estaço termina o seu comentário com um epifonema semelhante a tantos outros que, a despeito da sua reserva, quanto a exprimir emoções pessoais, lhe escapavam em determinados contextos:

Quanta Dei benignitas! Eum qui mercenarius esse uolebat, filium recipit.

Como é grande a bondade de Deus!

Recebe como filho aquele que queria ser assalariado.

ERAT AUTEM FILIUS EIUS SENIOR) Peccata nonunquam prosunt cum paenitentes ad se redeunt et bonum ipsum arctius complectuntur, quam qui in perpetua iustitia uixerunt.

Diligentibus enim Deum omnia cooperantur in bonum, "etiam peccata» ait Augustinus (Cf. Rom 8, 28). 
TU SEMPER MECUM ES) Laudatur in bono perseuerantia. Vos qui permansisti mecum in tribulatione mea (Rom 22, 28).

Tu semper, inquit, mecum es, quia qui cum Deo non est, moritur. Addit enim: Frater tuus hic mortuus erat; cum illo quidam fuerat pater.

Dir-se-ia que, neste comentário, com a preocupação de aproveitar o tema da perseverança, que ele vê desenhada no filho mais velho, Aquiles Estaço perde a direcção tomada no comentário à expressão erat autem filius eius senior, naquela referência ao facto de o pecado, uma vez assumido como tal, servir melhor, por vezes, o progresso espiritual do que a simples permanência na graça.

HAVIA, PORÉM, O FILHO MAIS VELHO) O pecado torna-se não raro frutuoso, quando os pecadores arrependidos entram em si e abraçam a prática da virtude com mais afinco do que os que sempre viveram em graça.

Para os que amam a Deus tudo contribui para o bem, "até o pecado», acrescenta Agostinho.

TU ESTÁS SEMPRE COMIGO) Louva-se a perseverança no bem. Vós que permanecestes a meu lado, nos meus trabalhos.

Tu, diz, estás sempre comigo, porque quem não está com Deus morre. Pois acrescenta: Este teu irmão estava morto; no entanto, com ele estivera o pai."

De facto, para a exegese contemporânea, como, aliás, para os autores espirituais, o filho mais velho, que na intenção de Lucas simbolizava os Escribas e Fariseus, é o protótipo da auto-satisfação do crente sem aspirações, que, a certa altura, vê em Deus, quando olha para Ele, mais um devedor do que um amigo.

Não era, até há pouco, um aspecto muito considerado, já que esta parábola, incorrectamente chamada de «Parábola do Filho Pródigo», era, em geral, lida como exemplo da dinâmica da conversão, quase sempre a partir do pecador.

O nosso humanista parece ter intuído a profundidade da revelação contida no discurso de Jesus, que fala essencialmente da misericórdia divina; mas não tira disso todas as consequências, em parte porque essa temática andava demasiado envolvida em questões especulativas sobre a justificação, a graça e a liberdade... quase como se tudo se passasse no coração do homem, num relacionamento pouco mais que jurídico com Deus.

Em jeito de síntese, pode dizer-se que Aquiles Estaço, nos seus comentários à parábola do Filho Pródigo, não esconde uma certa emoção, que se revela de modo especial quando procura tirar conclusões teológicas e ascéticas do texto evangélico. 
Isto é tanto mais digno de nota quanto é certo que a frieza caracteriza grande parte das suas notas, sempre marcadas pela preocupação científica que as carrega de observações de ordem filológica e citações de textos paralelos.

Por outro lado, é necessário não esquecer que Estaço faz o seu comentário já na segunda metade do século XVI, quando as tentativas de reconciliação entre católicos e protestantes pareciam fazer renascer as polémicas dos séculos III e IV sobre o modo de acolher os cristãos relapsos.

Pode dizer-se que a emoção do humanista português nasce também da intuição que o leva a ver na fala do pai com o filho mais velho pistas para um verdadeiro diálogo ecuménico.

Relativamente à teologia do pecado, que, apesar de não ser o tema directo da parábola, é o que desenvolve mais, aliás seguindo na esteira dos comentadores que o precederam, pode dizer-se o seguinte:

$\mathrm{Na}$ segunda metade do século XVI, a reflexão teológica sobre as relações da natureza humana com o pecado e a graça move-se entre dois extremos:

De um lado, o pessimismo dos predestinacionistas da linha de Calvino: Deus predestina para a salvação ou para condenação, independentemente dos méritos da pessoa. A estes podiam juntar-se alguns discípulos de Lutero, que, embora não fosse tão radical, ensinava que a natureza humana estava irremediavelmente corrompida e que o pecado era a sua condição normal.

Do outro lado, o optimismo naturalista de certos humanistas, consciente ou inconscientemente dependentes de Pelágio, que, esquecendo os efeitos do pecado sobre a natureza humana, concluíam quase negando a Redenção e a necessidade da Graça.

Aquiles Estaço evita os dois extremos, além do mais, pela sua preocupação de ortodoxia; o conteúdo das suas notas tem como fundo a doutrina dos decretos tridentinos, onde, contra ambos os extremos, se consagra a doutrina tradicional da Igreja, ao afirmar-se a capacidade da natureza humana para colaborar com a Graça.

Mas a Graça é absolutamente necessária, inclusivamente para o início da fé justificante, porque o homem já de si limitado, como criatura que é, leva consigo o peso da "raça» pecadora, a que pertence pela natureza, e dos seus próprios pecados. 